\title{
The Influence of Regrafting at Picea Pungens Var. Argentea and its Economic Efficiency
}

\author{
Georgel Constantin MAZĂRE ${ }^{* *}$ \\ ${ }^{1)}$ Department of Forestry, Stefan cel Mare University- 720229- Suceava, 13 Universitătii Street, \\ Romania \\ ${ }^{*}$ Corresponding author, e-mail: george_mazare@yahoo.com \\ Bulletin UASVM Horticulture 71(2) / 2014 \\ Print ISSN 1843-5254, Electronic ISSN 1843-5394 \\ DOI:10.15835/buasvmcn-hort:10099
}

\begin{abstract}
Picea pungens Argentea could be obtained both by generative and vegetative way. Considering that the main important feature of this species, the needles' colour, could lose in intensity by generative way, the vegetative remain the most important. One of the Picea pungens Argentea vegetative obtaining methods is the grafting method. The main problem of this method is its lower success, because even a lot of grafted exemplars seem to survive, in time a part of them will die. The purpose of this study is to see whether the stocks grafted once can be reutilized, taking into account the grafting success and the costs of obtaining them. For that it was made a bifactorial experiment, one of the factors being the stock and the other being the grafting level. For processing the data obtained it was used the Duncan test. Also, this study contains a calculation of economic efficiency, to see if the regrafting method have economically advantages too.
\end{abstract}

Keywords. Graft, rootstock, scions, Picea pungens, vegetative.

\section{INTRODUCTION}

Decorative by needles' color and in some cases by their port (Şofletea and Curtu, 2000), Picea pungens varieties are used in our country as decorative species having no forestry interest (Dumitriu-Tătăreanu, 1960).This species was introduced with experimental intention in some dendrologic parks (Mihalache, 1956; 1989), with no satisfactory results. With the aging of the specimens they lose the needles'color, thus recommending gradual replacement of old specimens with younger ones.

Even Picea pungens is one of the exotic conifer species that reach the fructification in Romanian parks and green spaces, the biggest problem is getting varieties of this species seedlings. And this because, although at begin the obtained specimens have the color of the parental variety, with the passage of time the color disappears (Rubţov 1958, Hill, 1989). So, the vegetative propagation remains the only possible way in order to obtain the specimens capable to keep a long period the needles' color.
The first grafting experiment with significant importance was made in 1840 by Marvier du Boisdhyver. There were grafted over 10,000 slips of Pinus nigra ssp on Pinus sylvestris laricio seedlings. The experiment was made in the forest Fontainbleau, France (Enescu, 1994).

Other grafting experiment is mentioned by Tyystijärvi and Karki (1969) cited by Enescu (1994), which in Finland, during 1962-1968, grafted a number of 300000 specimens of Picea abies, with an average the clamp about $68 \%$.

In Romania the softwood grafting is mentioned as practiced from the '50s (Rubţov, 1958), especially at the species Picea pungens var. glauca and Abies concolor.

Grafting experiments have been made recently with a clamping percent that reached about 70\% or more (Mazăre, 2008; 2010; Posedaru, 2005). Although this percentage may seem high, the grafting costs are high too.

The purpose of this paper is trying to reducing the costs by reusing grafted seedlings. More specifically, this paper proposes the study of the 
possibility of regrafting the specimens whose first graft failed and evaluation the economic efficiency of the operation.

\section{MATERIALS AND METHODS}

The experiences were made at the Mihai Viteazu nursery, belonging to Turda-Cluj, during three consecutive years.

Biological material used, consist of rootstocks and scions, came from species Picea abies and Picea pungens var. Argentea. The first species was used as rootstock seedlings, being used exemplars with a diameter between 4 and $6 \mathrm{~mm}$. The graft was taken from the second species, having about $7 \mathrm{~cm}$ length.

As grafting method it was used the side grafting. For this, it was consulted the older literature (Cristescu, 1975; Enescu, 1975; Luban, 1959) and the recent too (Drăghia, 2000 Florescu, 1999; Mateescu, 2002).

The experimental factors were the rootstock type and grafting level. Regarding the first factor, we choose two graduations of them, the grafting being made on the ungrafted rootstock and on the rootstock grafted once, in previously year. Regarding the grafting level, it had three graduations. So, the grafting was made on the first growth, on the second one and on the third one.

The behavior of grafted seedlings was followed throughout the growing season, with the work of care applied in the process, but the final inventory of survive grafting was not made until the end of the growing season. To interpret the results on grafting efficiency, expressed by number of alive slips, the data obtained from the measurements were statistically processed by variance analysis method, using the method of multiple comparisons (Duncan test, considering significant differences DS5\%).

\section{RESULTS AND DISCUSSIONS}

Tab 1 presents the sample variances and $F$ series of experiment executed in three years.

The second table (Tab 2) examines the influence of experimental years, rootstock type and their interaction on the number of living slips.

Tab. 1. The variance analyze for the $3 \times 2 \times 3$ experience. The influence of experiences years, stock type and grafting level on number of living grafts

\begin{tabular}{lcccc}
\hline$\quad$ Variability cause & SP & GL & $\mathrm{S}^{2}$ & The F probe \\
\hline & 334.83 & & & \\
Total & 0.78 & 53 & & \\
Blocks & 37.44 & 2 & & \\
The factor year & 17.80 & 2 & 18.72 & $8.85>3.32$ \\
The factor stock type & 72.44 & 1 & 17.80 & $8.42>4.17$ \\
The factor grafting level & 25.15 & 2 & 36.22 & $17.13>3.32$ \\
The interaction year x stock type & 80.78 & 2 & 12.57 & $5.95>3.32$ \\
The interaction year x grafting level & 24.15 & 2 & 20.19 & $9.55>2.87$ \\
The interaction stock type x grafting level & 4.41 & 4 & 1.07 & $5.71>3.32$ \\
The interaction year x stock type x grafting level & 71.89 & 34 & 2.11 & $0.52<2.87$ \\
Error & & & & \\
\hline
\end{tabular}

Tab. 2. The influence of experiences years and stock type on number of living grafts

\begin{tabular}{lccc}
\hline Experiences year & $\begin{array}{c}\text { Ungrafted } \\
\text { Sumber of living } \\
\text { exemplars) }\end{array}$ & $\begin{array}{c}\text { Grafted once } \\
\text { (number of living } \\
\text { exemplars) }\end{array}$ & $\begin{array}{c}\text { Average on } \\
\text { experiences year } \\
\text { (number of living } \\
\text { exemplars) }\end{array}$ \\
\hline First year & $12.67^{\mathrm{a}}$ & $11.67^{\mathrm{a}}$ & $12.17^{\mathrm{A}}$ \\
\hline Second year & $12.22^{\mathrm{a}}$ & $12.67^{\mathrm{a}}$ & $12.44^{\mathrm{A}}$ \\
\hline Third year & $12.00^{\mathrm{a}}$ & $9.11^{\mathrm{b}}$ & $10.56^{\mathrm{B}}$ \\
\hline Average on stock type & $12.30^{\mathrm{M}}$ & $11.15^{\mathrm{N}}$ & \\
\hline
\end{tabular}


The results of rootstocks type's influence on grafting's efficiency have a higher influence than the experimental years, and that's because the regrafting have positive results. Even the percentage of regrafting success is lower than normal grafting, on rootstocks ungrafted before, it represent a success. The percentage of living grafts considering regrafting process is $55.7 \%$. The difference of $5.7 \%$ compared with normal grafting, because of the lower value, is considered significant (Fig. 1).

Tab 3 shows the influence of rootstock type, grafting level and their interaction on grafting efficiency.

From the data presented in Table 3 it can be seen that the rootstocks which had not been previously grafted provide a grafting success higher than regrafting case, excepting the grafting on first level. Also, a larger number of living slips were recorded on normal grafting on second growth, respectively the grafting on the previous level in regrafting case. Considering that, the regrafting process is less expensive by reutilizing rootstocks from previous unsuccessful grafting, the difference of only 1.15 alive exemplars considered as significant is a real success.

Of all the variants, the best results are provided by grafting on the second growth made on the rootstock that has not previously been grafted. The worse results, with a difference of $22.8 \%$ from the upper variant were registered on the grafting of the third growth on rootstocks that had been grafted on previously year (Fig 2).

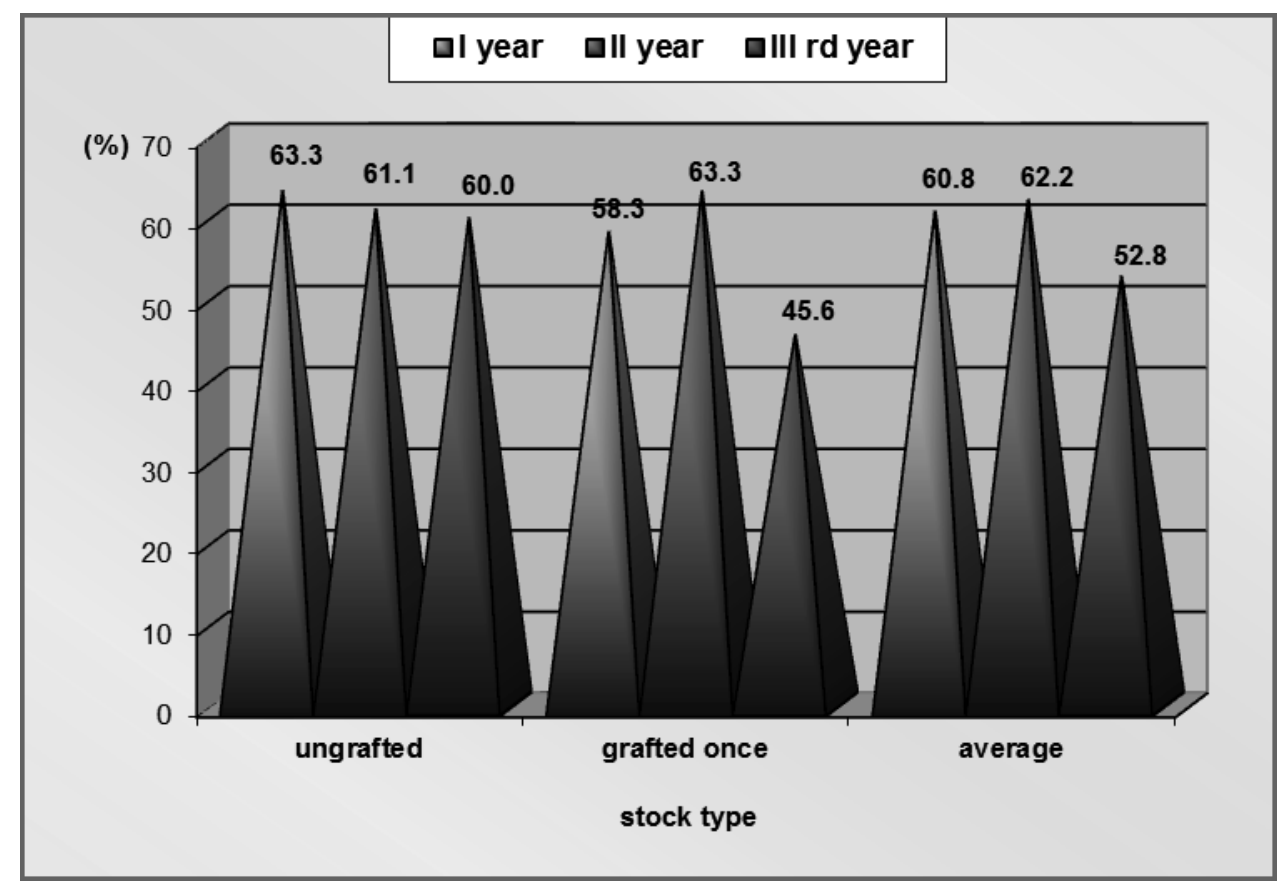

Fig. 1. The percentage of living grafts by experiences years, depending on stock type

Tab. 3. The influence of stock type and grafting level on number of living grafts

\begin{tabular}{|c|c|c|c|c|}
\hline Grafting level & Stock type & $\begin{array}{c}\text { Ungrafted } \\
\text { (number of living } \\
\text { exemplars) }\end{array}$ & $\begin{array}{c}\text { Grafted once } \\
\text { (number of living } \\
\text { exemplars) }\end{array}$ & $\begin{array}{c}\text { Average on } \\
\text { grafting level } \\
\text { (number of living } \\
\text { exemplars) }\end{array}$ \\
\hline First growth & & $11.33^{\mathrm{d}}$ & $11.44^{\mathrm{cd}}$ & 11.39B \\
\hline Second growth & & $13.56^{\mathrm{a}}$ & $13.00^{\mathrm{ab}}$ & $13.28 \mathrm{~A}$ \\
\hline Third growth & & $12.00^{\mathrm{bc}}$ & $9.00^{\mathrm{e}}$ & $10.50 \mathrm{~B}$ \\
\hline Average on stock type & & $12.30 \mathrm{M}$ & $11.15 \mathrm{~N}$ & \\
\hline
\end{tabular}




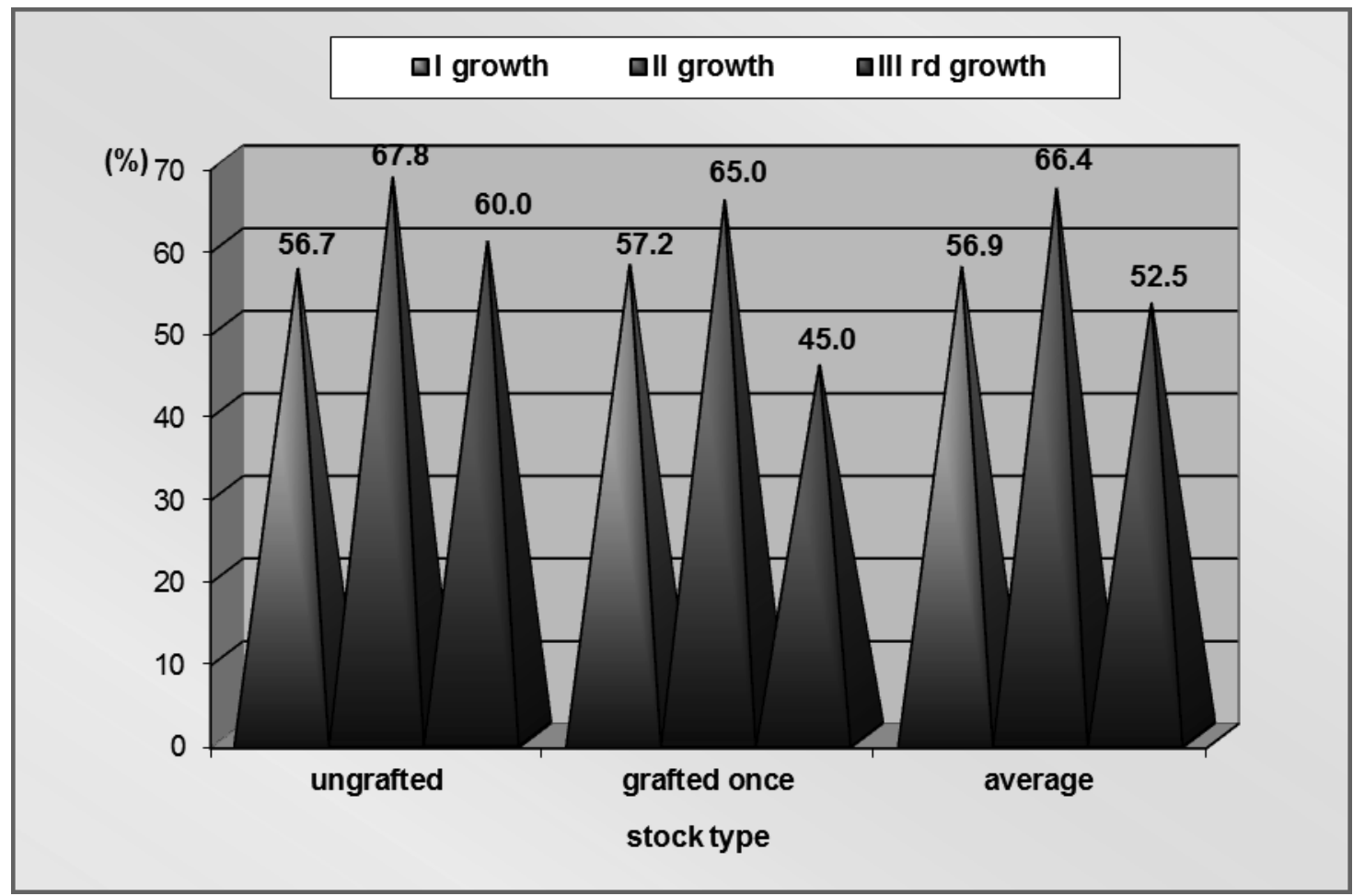

Fig. 2. The percentage of living grafts by grafting levels, depending on stock type

Tab. 4. Economical efficiency of regrafting method

\begin{tabular}{ccccccc}
\hline Grafting type & $\begin{array}{c}\text { Grafting success } \\
(\%)\end{array}$ & $\begin{array}{c}\text { Costs } \\
\text { (Eur/100 } \\
\text { pieces) }\end{array}$ & $\begin{array}{c}\text { Average sales } \\
\text { price } \\
\text { (Eur/piece) }\end{array}$ & $\begin{array}{c}\text { Gross income } \\
\text { (Eur/100 } \\
\text { pieces) }\end{array}$ & $\begin{array}{c}\text { Net income } \\
\text { (Eur/100 } \\
\text { pieces) }\end{array}$ & $\begin{array}{c}\text { Net income } \\
\text { rate } \\
(\%)\end{array}$ \\
\hline Normal & 61.5 & 93.6 & 2.3 & 139.8 & 46.1 & 49.3 \\
\hline Regrafting & 55.7 & 73.0 & 2.3 & 126.6 & 53.6 & 73.5 \\
\hline
\end{tabular}

In this experience is required an economic efficiency account to see whether regrafting, even if it have a lower success less than normal graftings, could be economically advantageous.

Regarding the cost of grafted seedlings in both versions, the difference lies only in the price of rootstock, and that because a spruce sapling must be led up to age 3 .

Workmanship for grafting is considered being the same. In regrafting case, even the percentage is smaller comparing with normal grafting, with rootstock ungrafted before, the economic calculation shows that this version brings an increase about 36 lei at 100 grafted rootstocks. This represents a rate of return of 73.5\% (Tab 4).

\section{CONCLUSION}

If we talk about grafting on first growth and grafting on third growth, the grafting level does not significantly influences the grafting success. Regarding the graft on second level, we can see an advantage of grafts placed on this level comparing with the other levels. The grafting on third growth is significantly weaker compared to second growth.

Even the regrafting on third level have no big success, regarding the number of alive exemplars, if we have a look on the table 4 we can conclude that it worth to make that kind of regrafting. So we can still consider regrafting method a real success, and that's because, even the grafting success is 
lower, we gain a year at the height of grafted plants and you could eliminate some costs.

Regrafting at Picea pungens var. Argentea ensure satisfactory results. Although, compared with the normal grafting with ungrafted rootstock, the difference of surviving grafts is significantly lower, this representing a gain by allowing rootstocks' reusing.

Regrafting the rootstocks that had no success following year is recommended in order to eliminate their manufacturing costs.

\section{REFERENCES}

1. Cristescu et al. (1975). Modern technologies for planting material (II). In: Horticulture, 2: 41-43.

2. Drăghia L (2000). Production of planting material. Ed. , Ion Ionescu de la Brad", Iaşi, 212 p

3. Dumitriu-Tătăreanu I (1960). Ornamental forest trees and shrubs grown in RPR. Ed. Agrosilvică, Bucureşti

4. Enescu V (1975). Improving main forest species. Ed. Ceres, București, 314 p

5. Florescu Gh (1999). Afforestation - Forest nurseries. Transilvania Brasov University, $151 \mathrm{p}$

6. Enescu V (1994). Vegetative propagation of forest trees. Ed.Ceres, Bucureşti, $336 \mathrm{p}$

7. Hill L (1989). Christmas trees: growing and selling trees, wreaths and greens. Storey Publishing, LLC, $152 \mathrm{p}$

8. Luban E (1959). Vegetative propagation of conifers. In: Garden, orchard and vineyard. 8: 48-50.
9. Mateescu R (2002). Ornamental trees and shrubs. Ed. M.A.S.T., Bucureşti, $218 \mathrm{p}$

10. Mazăre G (2008). Researches conducted in order to obtain Picea pungens var. Argentea by grafting. Bulletin USAMV Cluj-Napoca.Horticulture, 65(1): 402-406

11. Mazăre G (2010). Research on improving Picea species' planting material production technologies and diversify its valorification. University of Agricultural Sciences and Veterinary Medicine Cluj Napoca, PhD Diss. Abstr. 113220

12. Mazare G et al. (2010). The care in the first years of life of blue spruce obtained by grafting. Bulletin USAMV ClujNapoca.Horticulture, nr. 67(1): 524

13. Posedaru A (2005). Studies and research on effective methods of propagating ornamental varieties of the genera Abies, Picea and Chamaecyparis. University of Agricultural Sciences and Veterinary Medicine București, PhD thesis.

14. Mihalache A (1956). Aspects of acclimatization and enrichment of the collections of woody species in Hemeiusi and Dofteana forests, Bacau. In: Studies and researches- Forestry.

15. Mihalache A (1989). Hemeiusi forest's monography. RDPTA Bucureşti, $248 \mathrm{p}$

16. Şofletea N and Curtu L (2000). Dendrology. Editura Pentru viaţă, Brașov, Romania.

17. Rubţov Şt (1958). Culture of woody species in nurseries (forest and decorative). Ed Agro-Silvică de stat, Bucureşti, $448 \mathrm{p}$. 